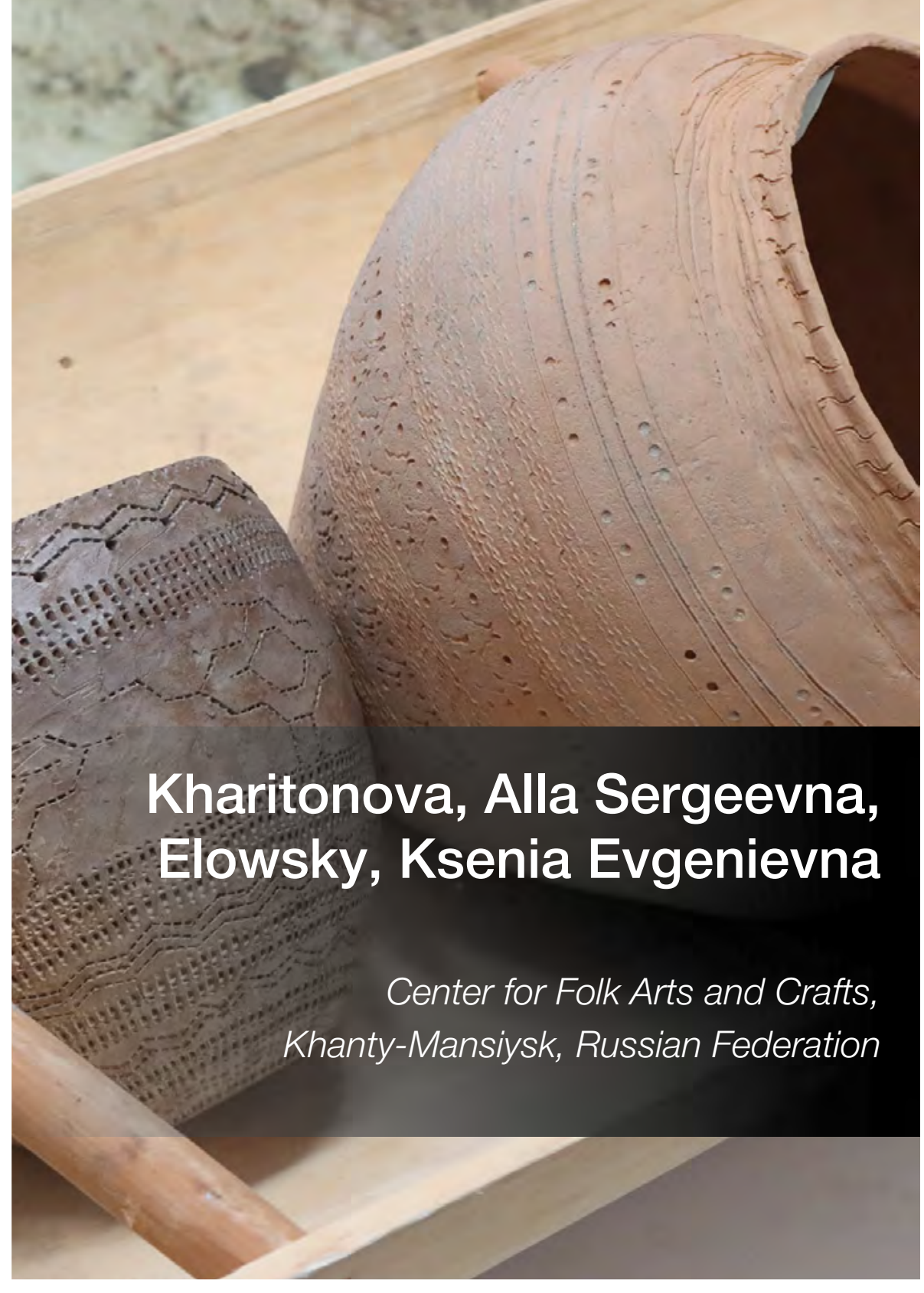

Харитонова Алла Сергеевна, Илауски Ксения Евгеньевна

Центр народных художественных промыслов и ремесел, г. Ханты-Мансийск, Российская Федерация

\title{
ХРАНИТЕЛИ ЮГОРСКИХ ТРАДИЦИЙ
}




\section{АННОТАЦИЯ}

С 1 октября по 30 декабря 2020 года в Ханты-Мансийске, в Доме-музее народного художника СССР В.А. Игошева, состоялась выставка «Четверть века сохраняя традиции». Посвященная юбилею Центра народных художественных промыслов и ремесел Югры, она явилась итогом его двадцатипятилетней работы, многочисленных проектов, научных исследований, экспедиций и конкурсов. Статья представляет обзор экспозиции, в которой показаны произведения разных техник и направлений народного искусства: резьба по дереву, вышивка и плетение, народный костюм, керамика. Материалы, сюжеты, формы, орнаменты и мотивы связаны с мифологическими представлениями обСКИх угров.

\section{КЛЮЧЕВЫЕ СЛОВА:}

Народное искусство; обские угры; коренные народы; реконструкция; юбилейная выставка.

\section{ABSTRACT}

From October 1 to December 30, 2020, the exhibition "A quarter of a Century preserving Traditions" was held in Khanty-Mansiysk. Dedicated to the anniversary of the Center of Folk Arts and Crafts, it was the result of its twenty-five years of work, numerous projects, scientific research, expeditions and competitions. The article presents an overview of the exposition, which shows works of different techniques and directions of folk art: wood carving, embroidery and weaving, folk costume, ceramics. Materials, plots, forms, ornaments and motives are associated with the mythological ideas of the $\mathrm{Ob}$ Ugrians.

\section{KEYWORDS:}

Folk art; Ob Ugric peoples; indigenous peoples; Khanty; Mansi; reconstruction; anniversary exhibition. 


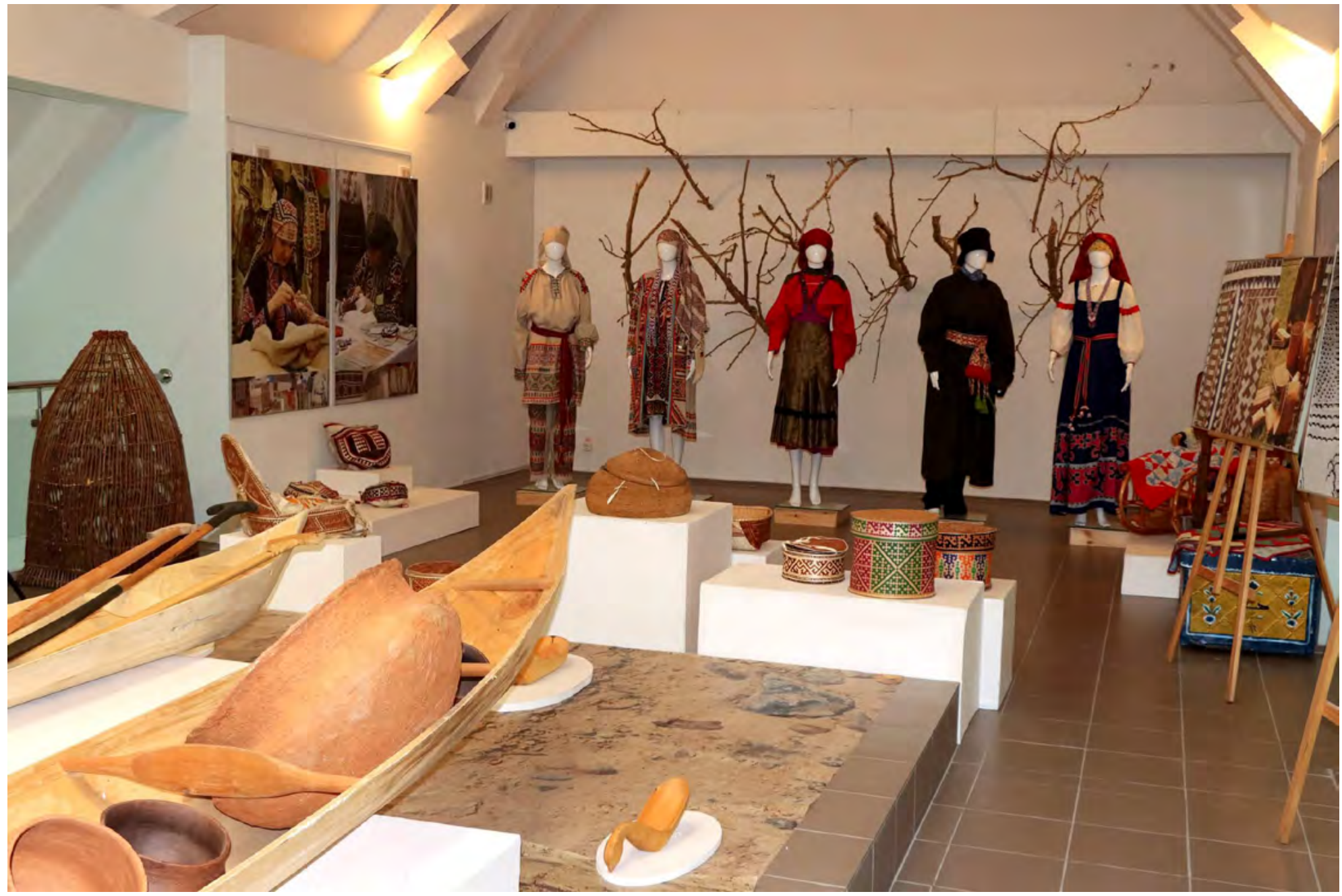

В Ханты-Мансийске в Доме-музее народного художника СССР В.А. Игошева с 1 октября по 30 декабря 2020 года состоялась выставка «Четверть века сохраняя традиции». Посвященная юбилею Центра народных художественных промыслов и ремесел, она явилась итогом его двадцатипятилетней работы, многочисленных проектов, научных исследований, экспедиций и конкурсов.

Смысловым центром экспозиции выставки стали плывущие под потолком ковши-утки и лодкидолбленки (обласы) и глиняные сосуды. Последние - реконструкция древней керамики, встречающейся в регионе.

Почему именно лодка и птица? Потому что в мифологии обских угров ${ }^{2}$ в начале земного творения была бескрайняя Вода, в которую, исполняя волю бога-творца Нум-Торума ${ }^{3}$, нырнула за землей гагара (в других вариантах мифа - утка) ${ }^{4}$. Потому что жизнь, в том же мифе, как река, льется с неба. Потому что без лодки все, кто живет в Югорском крае, себя до сих пор не мыслят.

Мы - наше восприятие, обусловленное природной и социальной средой, индивидуальным опытом и традицией (значимым для нас авторитетом), а также способностью выйти за границы любого опыта и знания и столкнуться с реальностью непосредственно. То, из каких представлений мы смотрим, оказывает не меньшее воздействие на то, что мы увидим, чем точка, с которой мы обозреваем «окрестности»: луч фонаря может выхватить из темноты лист дерева, глаза хищника или наш страх, принявший форму того, чего мы боимся.

И мифы, лежащие в основе любой народной традиции, - это и образы, хранящие в себе информационные следы - опыт всех поколений людей, живших на той или иной территории, и первоначальные архетипические структуры нашей психики. Если бы последние не были всеобщими, у нас не было бы шанса понять другого человека, другую культуру, другую эпоху, минуя знания языка и контекст. Но если мы не знаем, как эти базовые структуры работают в практике конкретной народной традиции, то стоящее за ее предметным или символическим рядом содержание останется непонятым в своей уникальности. А значит, будет потерян целый пласт истории человека, появится еще один «мертвый» язык, пробел в понимании того, «кто мы, откуда пришли и куда идем».

Работая на протяжении многих лет с орнаментами, с их знаками, смыслами народной культуры, специалисты Центра ремесел создали экспозицию на основе обско-угорской мифологии и личного
1. Выставка «Четверть века сохраняя традиции».

Фото: Центр народных художественных промыслов и ремесел, Ханты-Мансийск, 2020 
2. Центр экспозиции. Фото: Центр народных художественных промыслов и ремесел, Ханты-Мансийск, 2020

\section{3. Лодки-долбленки.} Фото: Центр народных художественных промыслов и ремесел, Ханты-Мансийск, 2020
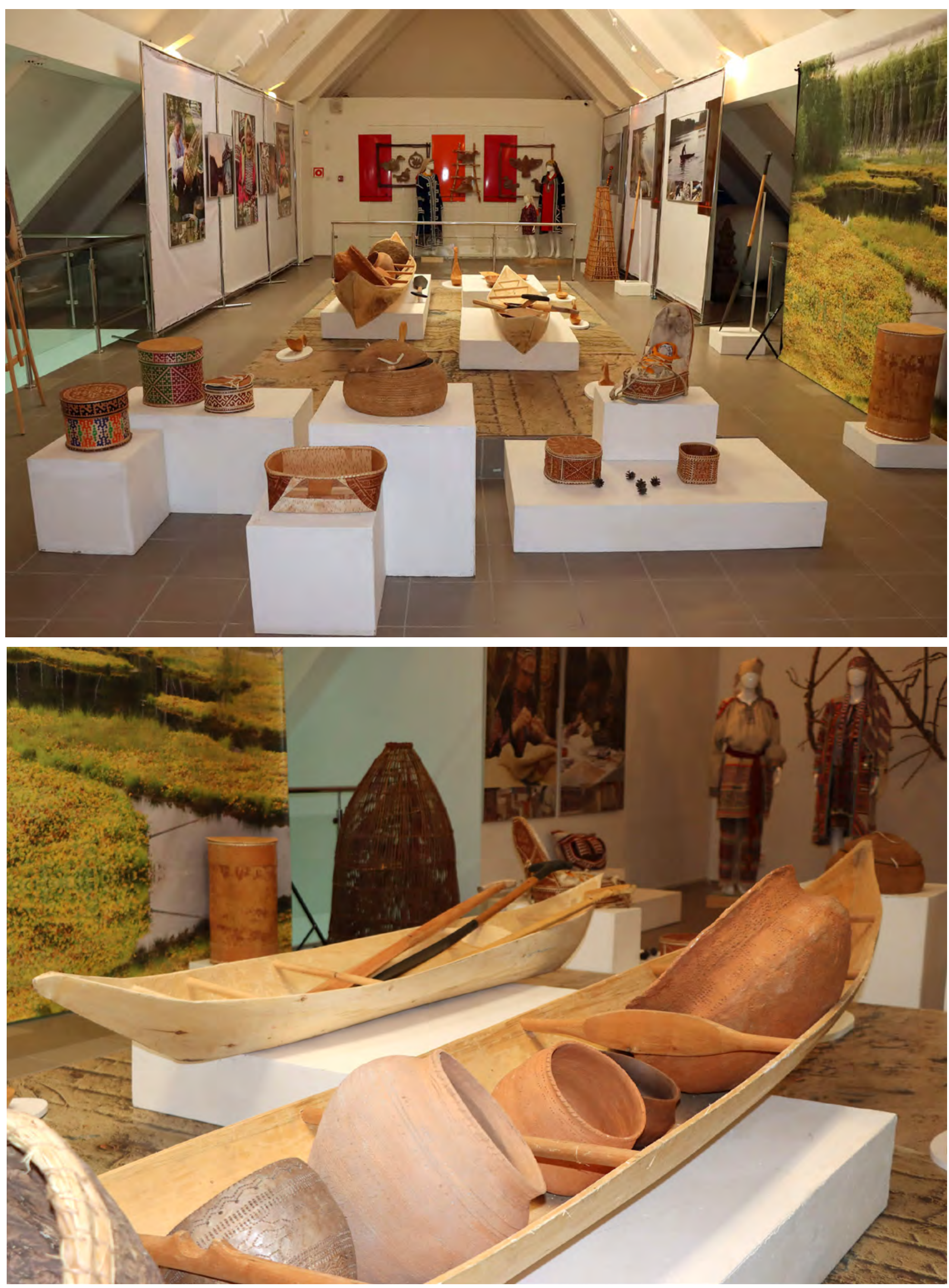


\section{Искусство Евразии}

№1 (20) 2021 eISSN 2518-7767

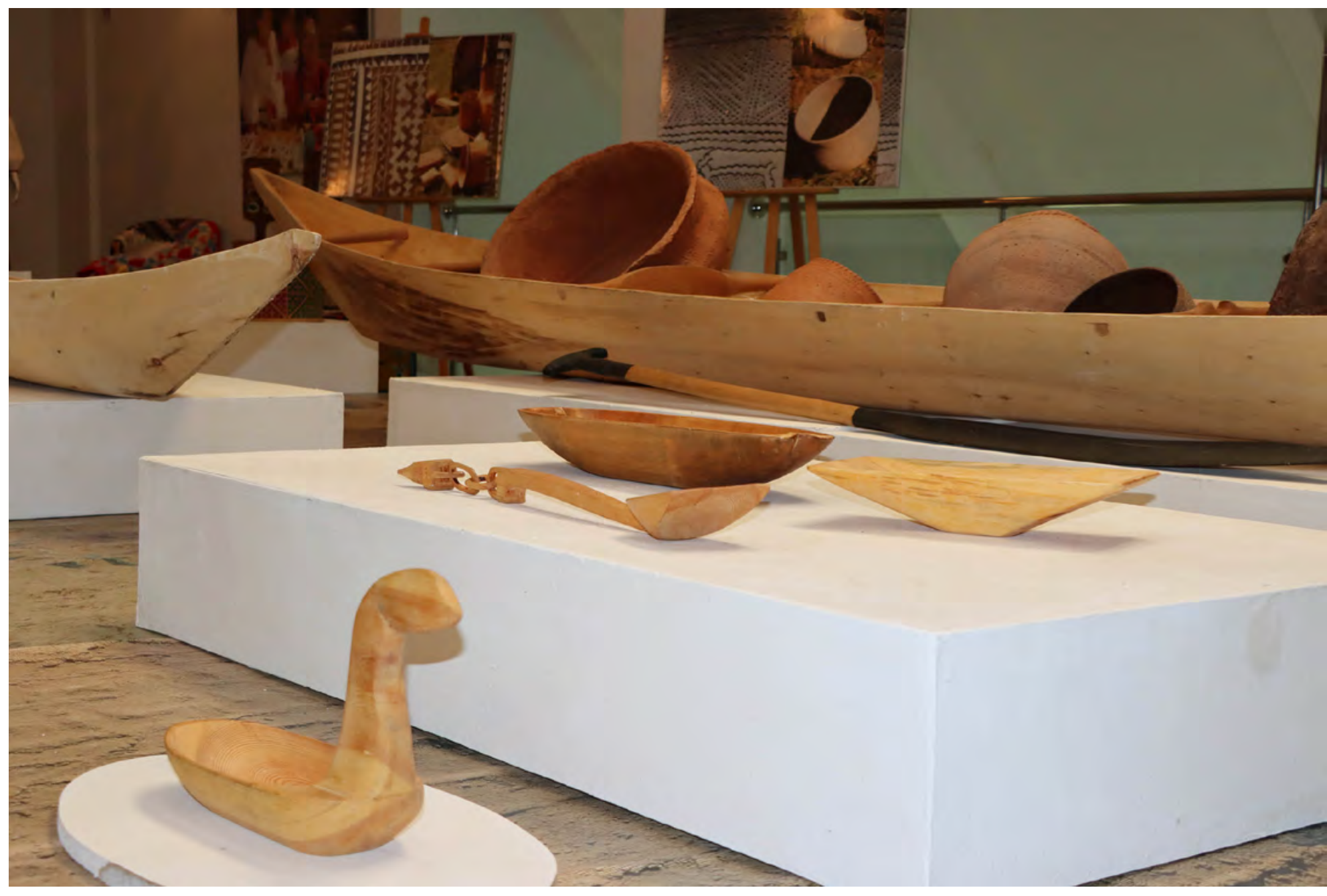

знания «словаря» Югорской природы и художественной традиции.

Ханты-Мансийский автономный округ - Югра можно назвать «водным» краем: реки и речушки пересекают его, как дорожки, то выводя, то заманивая в таежные глухомани - туда, где цвет голубой тайги смыкается на рассвете с цветом неба, туда, где прозрачность и настой трав, где прячутся корни преданий и сказок. Путь/дорога Река всегда была в центре здешней мифологии, то как река жизни и смерти, то как река земного пути, то как река потустороннего странствия душ шаманов и сказителей.

Река, тождественная жизни, - один из коренных мифов человечества. Это и реки, текущие с неба, и река-небо, и подземные воды, это и вполне реальные Ганга и Волга, и Иордан, и Желтая Река, и Янцзы, и Амударья, и Обь, и Иртыш... Что касается Западной Сибири, то люди издавна селились здесь по берегам рек. Лес и река давали в равной мере всё необходимое, но если запасы леса истощались в неурожайные годы, то оставалась всегда река - великая мать-кормилица, изобилующая рыбой. Особенно ярко связь с рекой прослеживается в жизни ханты и манси, неслучайно они называются речными людьми, рыбоядцами: они ели рыбу и муку из нее, шили обувь. И рода свои они называли и называют по тому, у какой реки и в какой ее части живут. И так до сих пор: есть сосьвинские (река Сосьва), есть лозьвинские (река Лозьва), пелымские (река Пелым), кондинские (река Конда) манси, есть иртышские, демьянские (река Демьянка), ваховские (река Вах), аганские (река Аган), пелымские тромъеганские (река Тромьёган), казымские (река Казым) ханты и т. д.

Именно поэтому в центре экспозиции - лодки, а визуальный проект «Река. Лодка. Жизнь» стал смысловым центром юбилейной экспозиции, выстраивая вокруг себя другие смысловые части выставки. Этот проект был впервые представлен на площадке «l Международного конгресса традиционной художественной культуры: фундаментальные исследования народного искусства» в Ханты-Мансийске в 2011 году. Он рассказывал о том, что устройство дома, лодки или символика орнамента - это язык, слова которого носятся в воздухе, смотрят звездами, плещутся в белых ночах северных рек.

И обласы на фотографиях, и обласы, плывущие в пространстве зала, в равной мере документальны и символичны: ведь лодка (об этом рассказывают мифы и легенды многих народов) — это

\section{4. Ковши-утки.}

Фото: Центр народных художественных промыслов и ремесел, Ханты-Мансийск, 2020 

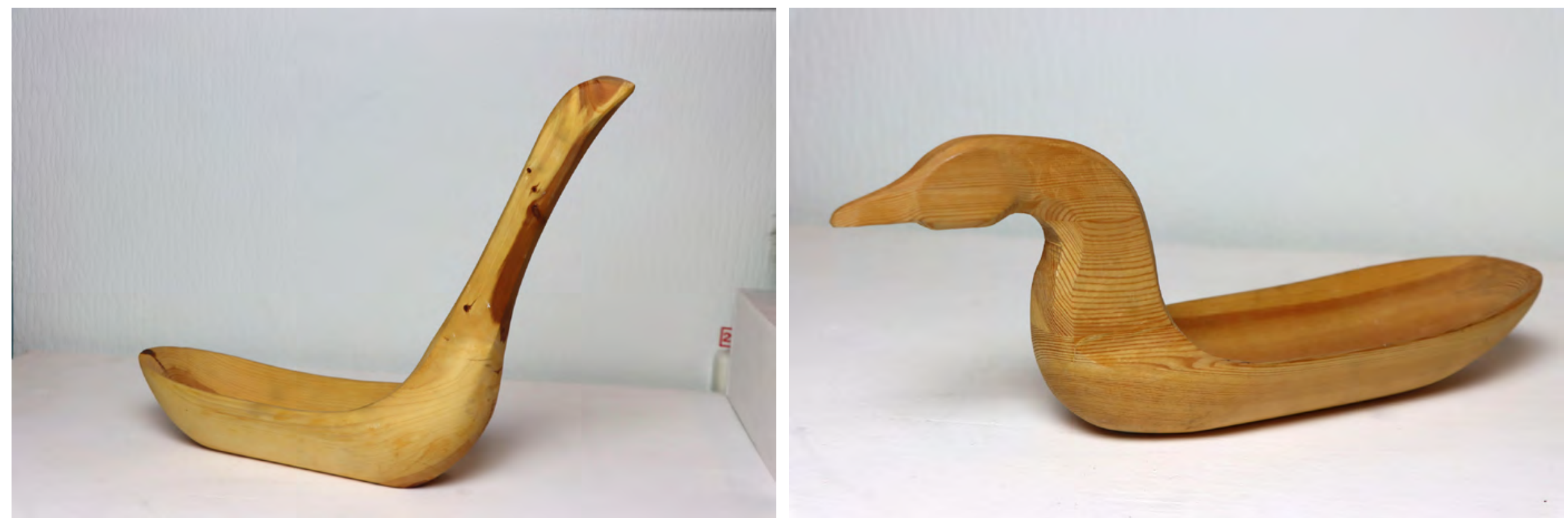

\section{5. Ковш-утка.}

Выставка «Четверть века сохраняя традиции".

Фото: Центр народных художественных промыслов и ремесел, Ханты-Мансийск, 2020

\section{6. Ковш-утка. Выставка «Четверть века} сохраняя традиции». Фото: Центр народных художественных промыслов и ремесел, Ханты-Мансийск, 2020

\section{7. Изображение птицы.}

Выставка «Четверть века сохраняя традиции".

Фото: Центр народных художественных промыслов и ремесел, Ханты-Мансийск, 2020

\section{8. Ковш-утка. Выставка}

\section{“Четверть века}

\section{сохраняя традиции".}

Фото: Центр народных

художественных промыс-

лов и ремесел,

Ханты-Мансийск,

2020

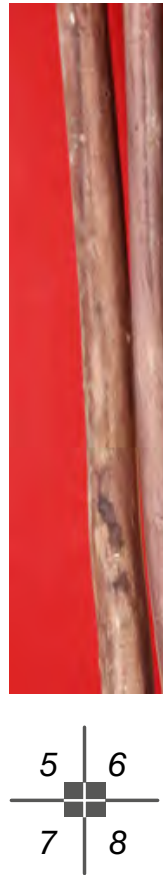

и средство для путешествия по водам судьбы, и то, что отвезет тебя к твоим предкам, когда ты отправишься к ним навстречу, в последний путь, и предмет быта, без которого непредставима жизнь таежных охотников и рыболовов. Пропорции такой лодки выверены многовековым опытом и точно «подогнаны» к нраву местных рек, в них нет ничего лишнего, ничего не продуманного, ничего не «отмерянного и отрезанного» традицией.

Для изготовления обласа используются стволы кедра, осины, тополя-осокоря, причем желательно найти дерево не с прямым стволом, а с прогибом, чтобы впоследствии выгнутая сторона стала дном лодки. После того как дерево валят, мастер отрубает нужный кусок, в зависимости от того, на сколько человек будет рассчитан облас: два размаха рук - это обласок на одного человека. Лодка должна быть легкой, чтобы ее можно было носить на плече по таежным тропам. Готовая лодка - светлая, слишком заметная на воде, а потому, чтобы придать ей «невидимость», ее натирают смесью сажи с сосновой или пихтовой смолой.
Легкая, бесшумная, без киля, со слегка уплощенным днищем, лодка летит-скользит по речной глади, как птица по небесной реке.

Недаром обские угры называют облас «юркой лодкой», управлять ею очень непросто, необходимо постоянно держать баланс, так как она буквально чувствует каждое течение. Иногда со стороны кажется, что лодка застыла на речной глади и сидящий в ней человек не делает ни одного взмаха веслом. Но это не так, просто его движения совсем незаметны, находятся в динамическом равновесии с водными потоками. Одно резкое движение и лодка сразу перевернется 5 .

Весла к такой лодке тоже не делаются наспех. Для них берут только ель, и то не любую, а только кремлевую, т.е. заплывшую с южной стороны смолой. Весло натирают той же смесью, что и облас, и лишь небольшую поперечину с орнаментом изящным символом волны - оставляют белой.

В экспозиции, кроме обычных весел, представлено и разноцветное свадебное весло, в прорези рукояти которого вставлены нанизанные 

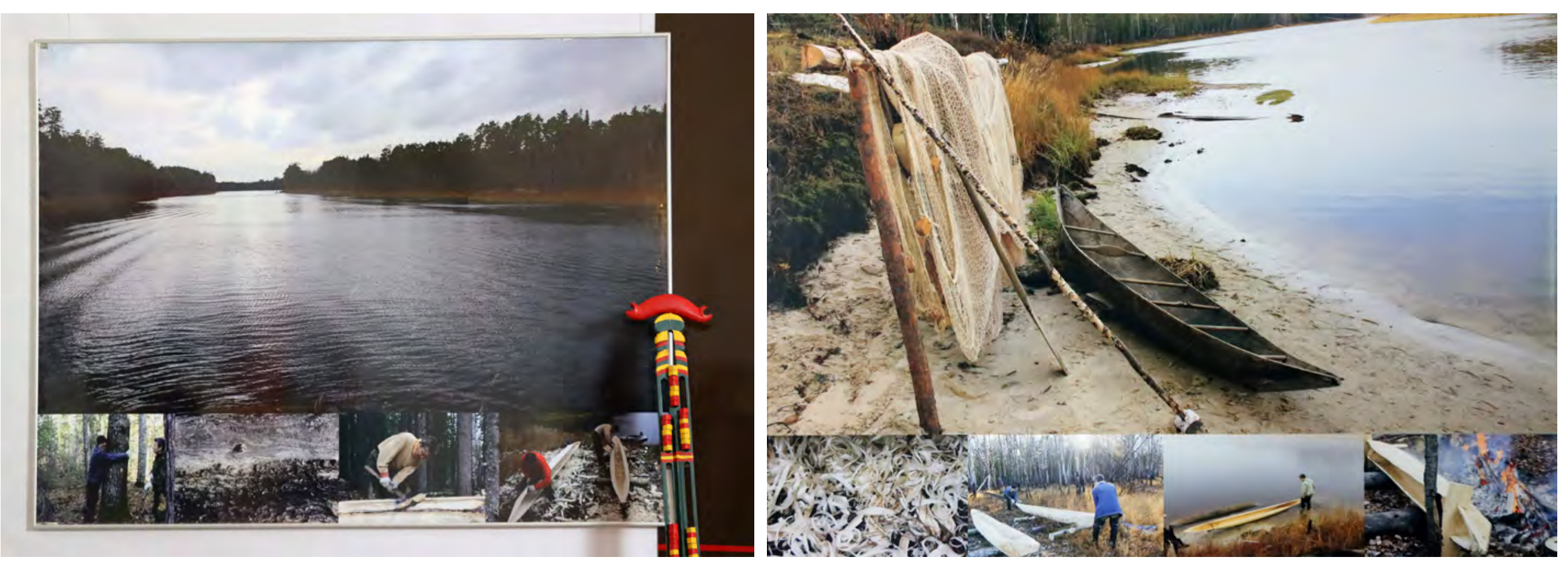

на стержень кусочки дерева. При гребле весло звенит-шумит-переливается, как погремушка, рассказывая невесте о том, что ее жених приближается, задолго до его появления (ведь звук над водой разносится хорошо).

Глиняные сосуды, плывущие по воде жизни, в одной из лодок - это реконструкция древней керамики (эпох энеолита, поздней бронзы), выполненная художниками Центра ремесел по региональным археологическим источникам. Простота форм рифмуется с простотой узора, последний делит сосуд на три зоны - три мира: верхний (венчик), средний (тулово сосуда) и нижний (придонная часть). Иногда узор отсутствует, и тогда символична сама форма, ее первобытная красота, словно обнаженное человеческое тело.

«Телесность» керамики всегда ощущается, когда смотришь на сосуды «начальных» эпох, еще не знавших глазурь и сложные приемы декора. В этой телесности - архаичная мощь, когда функциональность едина с сакральным смыслом предмета: вместилище для пищи, воды, праха древние сосуды просты и естественны, как жизнь человека в своих первоосновах.

Один из проектов Центра ремесел - «О чем молчит Марьина гора?». ${ }^{6}$ Это комплексное исследование керамического ремесла в Кондинском крае, в ходе которого реконструированы технологии разных временных эпох: ручная лепка, прядение, одноигольное вязание, вышивка, плетение. Но основное - керамические сосуды. Как говорит художник Светлана Лебедева: «Сколько я видела останков керамики, на территории Марьиной горы встречаются самые искусные, самые разнообразные орнаменты, причем хорошо сохранившиеся».
Исследователи относят черепки к лозвинской, атлымской, кулайской археологическим культурам?. Целых сосудов здесь не находят, и никому еще не удавалось по черепкам собрать целый кувшин или горшок, но черепки действительно уникальные - с самыми разнообразными и самыми мастерски исполненными узорами, которые даже при современной технике повторить мастеру не всегда просто, а иногда и не получается достигнуть такого уровня мастерства.

О начале этого орнаментального разнообразия рассказывает легенда проекта. Жила-была женщина манси, лепила она ловко горшки для еды и воды, но однажды задумалась, загляделась на летнюю изукрашенную цветами и ягодами тайгу. Подумала она: «Почему всё так украшено, а мои горшки нет?» И захотелось ей сделать творения своих рук такими же узорчатыми, как природа. Только придумать она ничего не могла. Пока не увидела следы лап птиц и зверей и не нанесла их на поверхность своих сосудов. Так родилось многообразие орнамента.

В одном небольшом зале музея, конечно, невозможно разместить всё то, что Центр ремесел делал и делает за последние 25 лет. Но можно передать образ этого «делания». В экспозиции есть и уникальная береста с локальными стилевыми особенностями, и сокровище Западной Сибири праздничный вышитый костюм остяков и вогулов, комплекты одежды народов коми (зырян), русских старожилов, лоскутное шитье, расписные прялки, плетеные сани и многое другое.

Визуальный проект «Лицо мастера» - фотографии мастеров за работой — представляет галерею ведущих мастеров Югры разных национальностей
9. Визуальный проект «Река. Лодка. Жизнь». Фото: Центр народных художественных промыслов и ремесел, Ханты-Мансийск, 2020

\section{0. Визуальный проект} «Река. Лодка. Жизнь». Фото: Центр народных художественных промыслов и ремесел, Ханты-Мансийск, 2020 

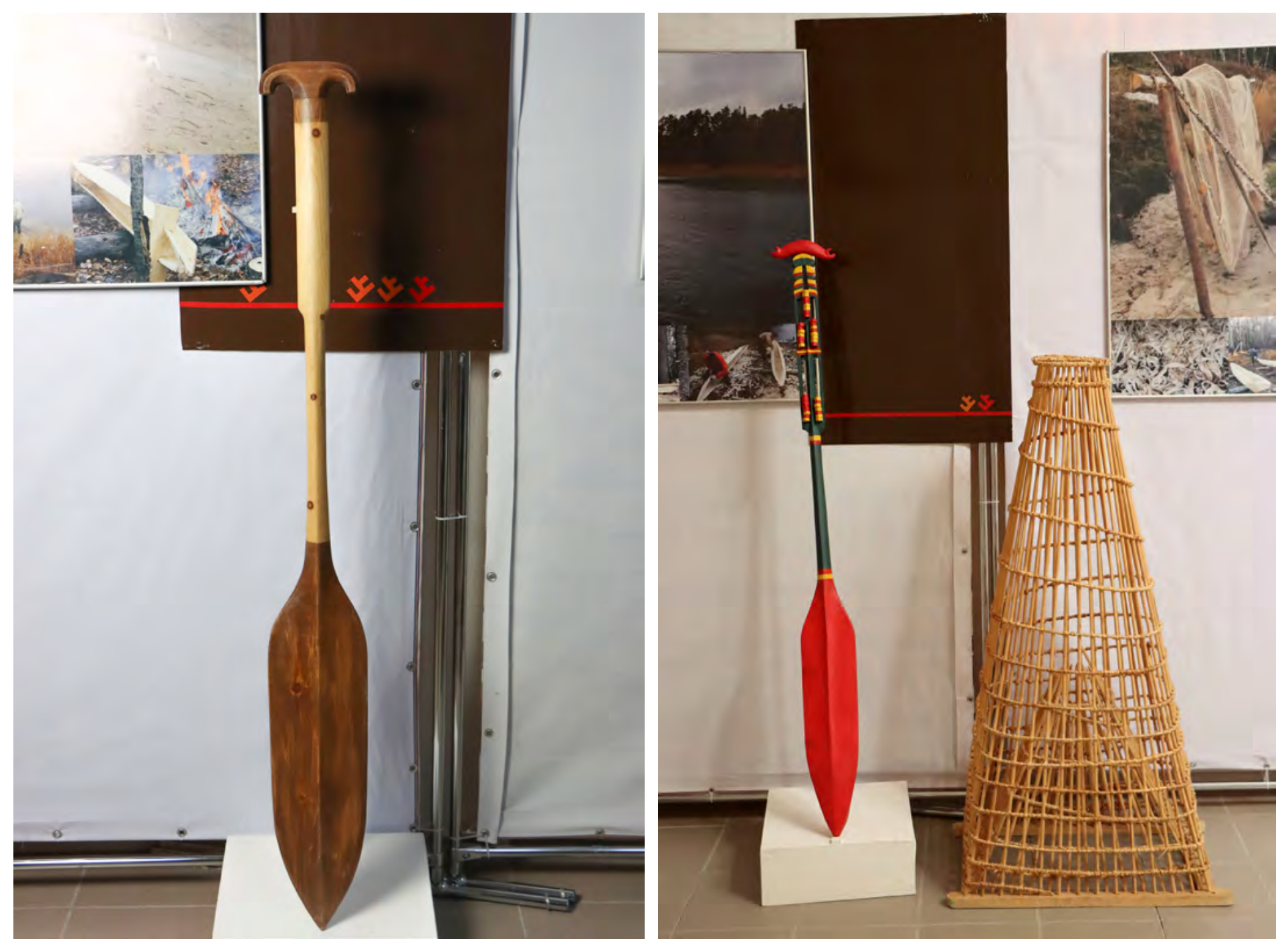

\section{1. Весло.}

Фото: Центр народных

художественных

промыслов и ремесел,

Ханты-Мансийск,

2020

12. Свадебное весло. Фото: Центр народных художественных

промыслов и ремесел, Ханты-Мансийск, 2020

\section{3. Рукоять}

\section{свадебного весла.}

Фото: Центр народных художественных промыслов и ремесел, Ханты-Мансийск, 2020

\section{4. Весло.}

Фото: Центр народных художественных промыслов и ремесел,

Ханты-Мансийск, 2

020
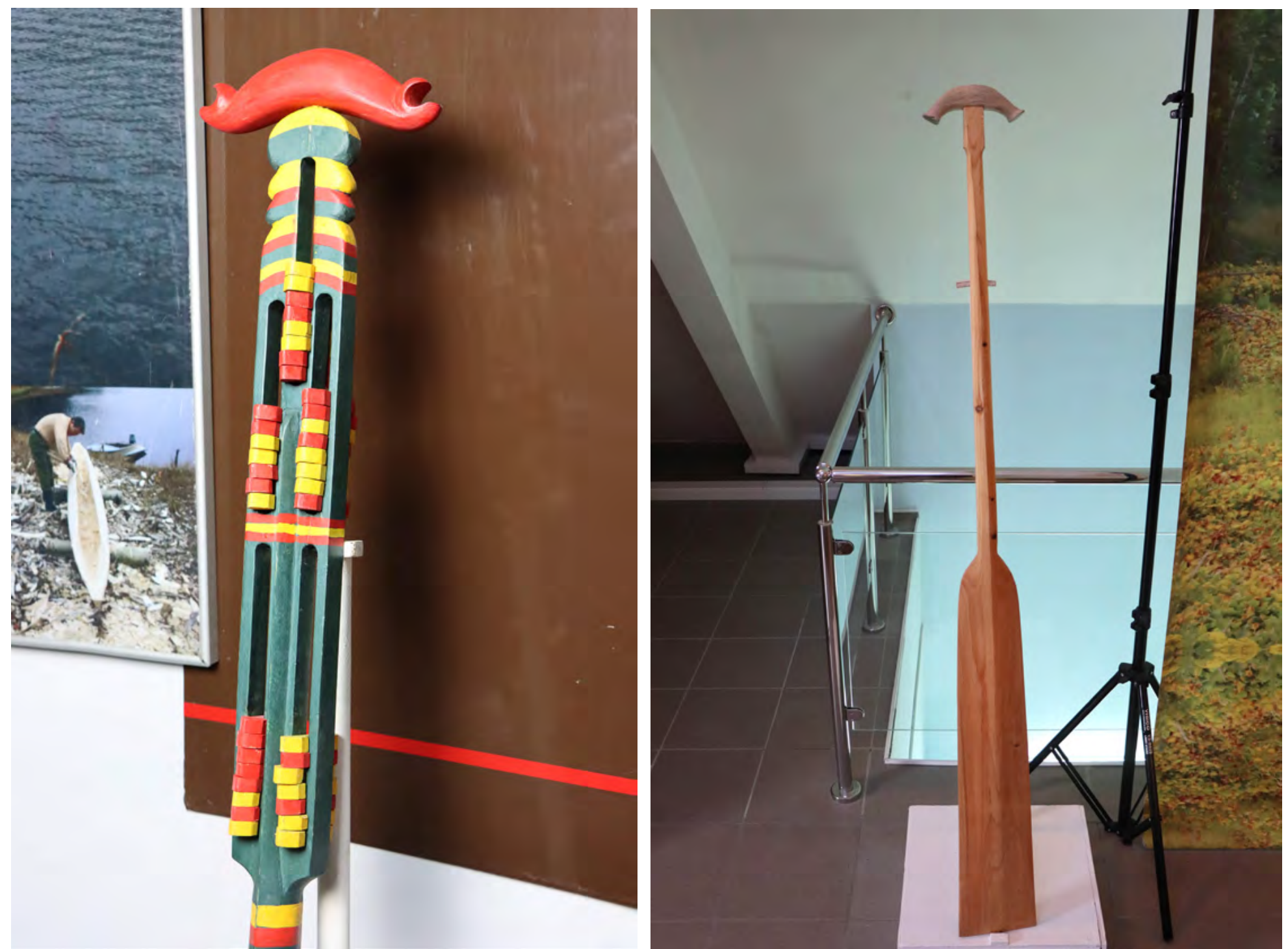


\section{Искусство Евразии}

№1 (20) 2021 eISSN 2518-7767
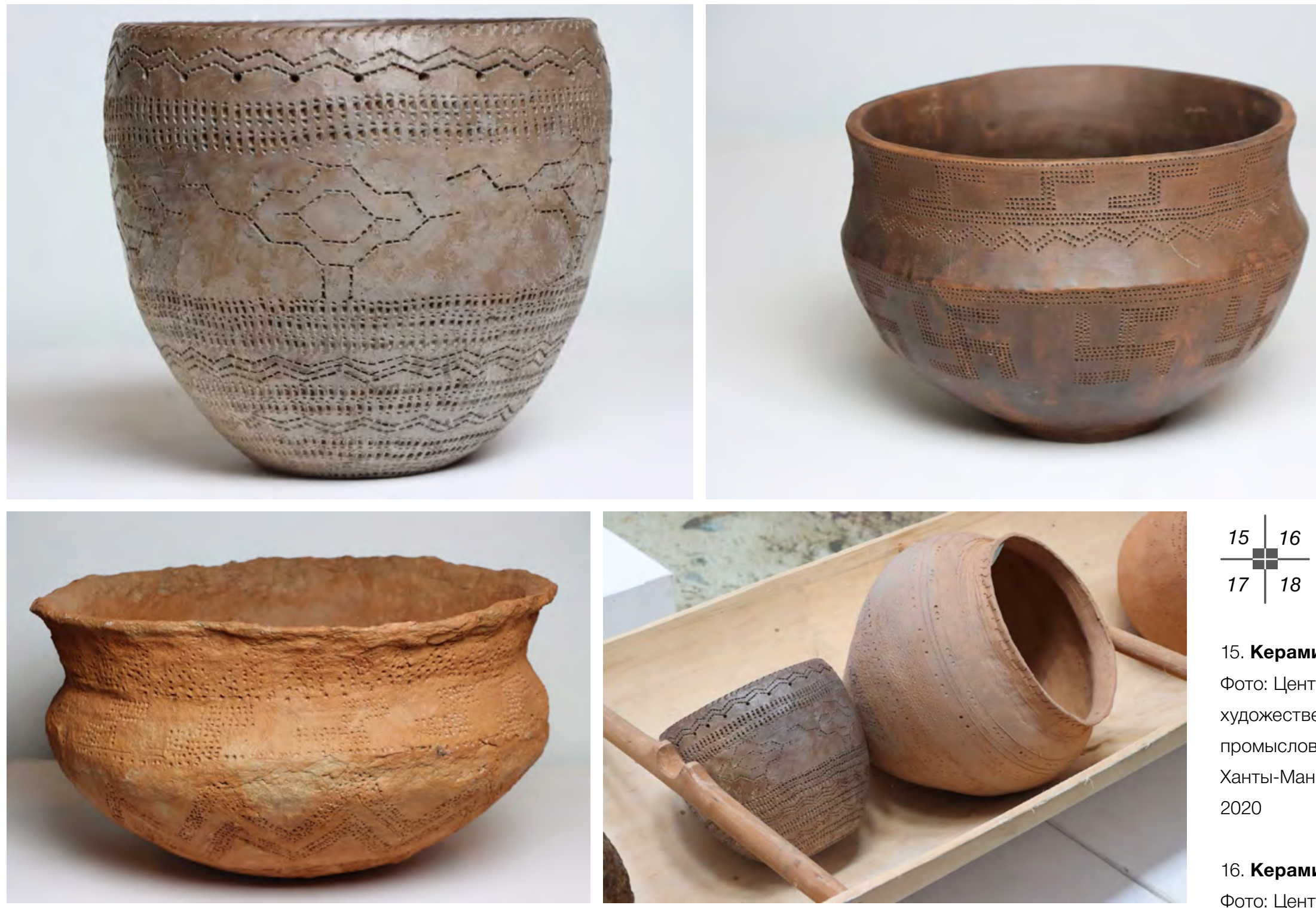

\section{5. Керамика.}

Фото: Центр народных художественных промыслов и ремесел, Ханты-Мансийск, 2020

\section{6. Керамика.}

Фото: Центр народных художественных промыслов и ремесел, Ханты-Мансийск,

и художественных традиций. Всё это позволяет увидеть объем проделанного и приоткрывает дверь в богатейшие фонды Центра ремесел, в которых народная культура - не только дело музейное, но и то, что вдохновляет мастеров-художников на создание современных произведений.

О юбилейном проекте Владимир Борисович Кошаев $^{8}$, постоянный участник и эксперт многих проектов Центра, говорит: «Сама выставка похожа на лодку - так обыграно пространство в пространстве. Это показатель высокого понимания внутренней задачи культуры проекта. Эти четверть века проходили на наших глазах, и мы сотрудничали в самых разных моментах: сначала с Удмуртским госуниверситетом в рамках программы Министерства образования "Народная художественная культура в проблемах знания, образования, творческой практики и производства", позже было еще несколько проектов, в том числе по проблемам онтологии народного искусства. Участие в них принимали студенты и преподаватели факультета искусств МГУ имени М.В. Ломоносо- ва и МГХПА имени С.Г. Строганова. На мероприятия были привлечены учащиеся и профессора вузов Нижневартовска, Сургута, РАН и РАО. Участие археологов, искусствоведов, этнографов, антропологов, культурологов, педагогов разных учреждений образования (от детских и школьных до профессиональных), а также иностранных специалистов показало огромный интерес к работе Центра ремесел Югры по реконструкции культурного и художественного наследия».

Выступая организатором и участником региональных, общероссийских и международных проектов, Центр ремесел инициирует необходимый сегодня разговор о стандартах художественной народной культуры, проводит экспертизу промыслов на основе этнографических и археологических исследований, тем самым возвращая народной культуре «знак высокого качества». Работая с разной возрастной аудиторией, команда сотрудников Центра ремесел находит новые форматы работы, новые красочные способы подачи материала, что и делает его одним из самых инновационных культурных пространств современной России.
2020

\section{7. Керамика.}

Фото: Центр народных художественных промыслов и ремесел, Ханты-Мансийск, 2020

\section{8. Керамика.}

Фото: Центр народных художественных промыслов и ремесел, Ханты-Мансийск, 2020 
19. Праздничный Вышитый костюм.

Фото: Центр народных художественных

промыслов и ремесел, Ханты-Мансийск, 2020

\section{0. Берестяной} туес с орнаментом. Фото: Центр народных художественных промыслов и ремесел, Ханты-Мансийск, 2020

\section{1. Берестяной} туес с орнаментом. Фото: Центр народных художественных промыслов и ремесел, Ханты-Мансийск, 2020

\section{2. Берестяная} коробка с орнаментом. Фото: Центр народных художественных промыслов и ремесел, Ханты-Мансийск, 2020
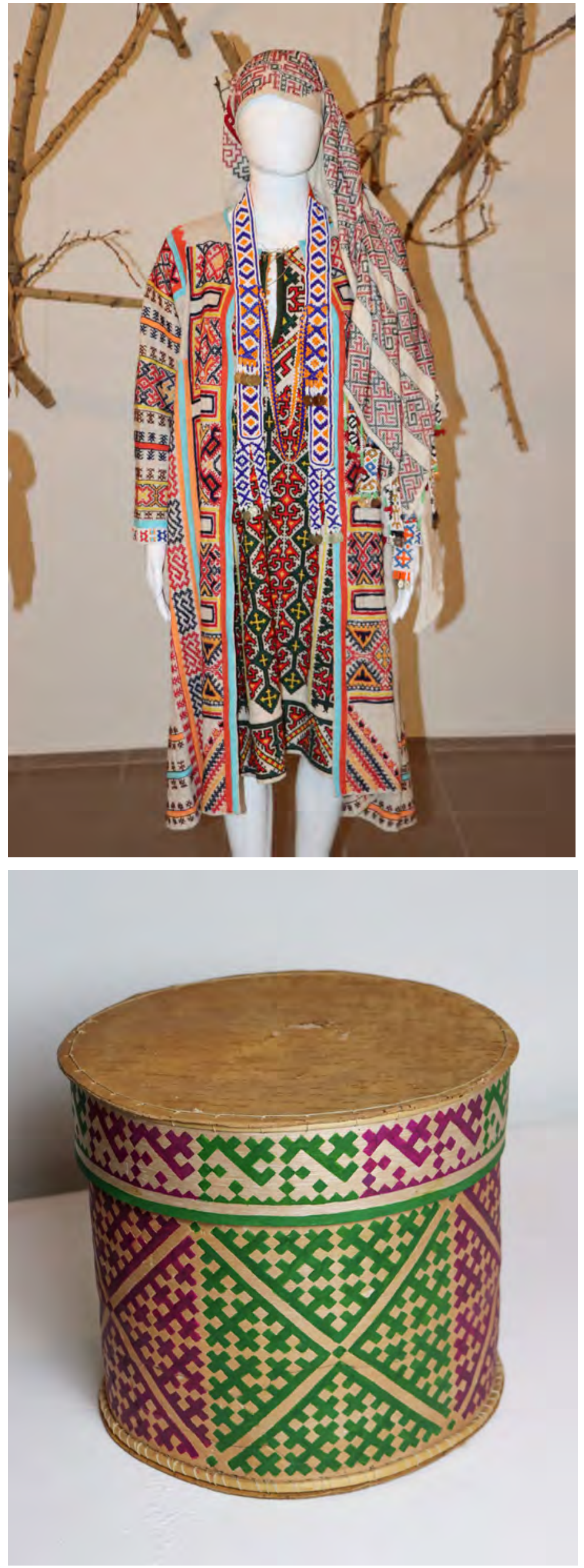
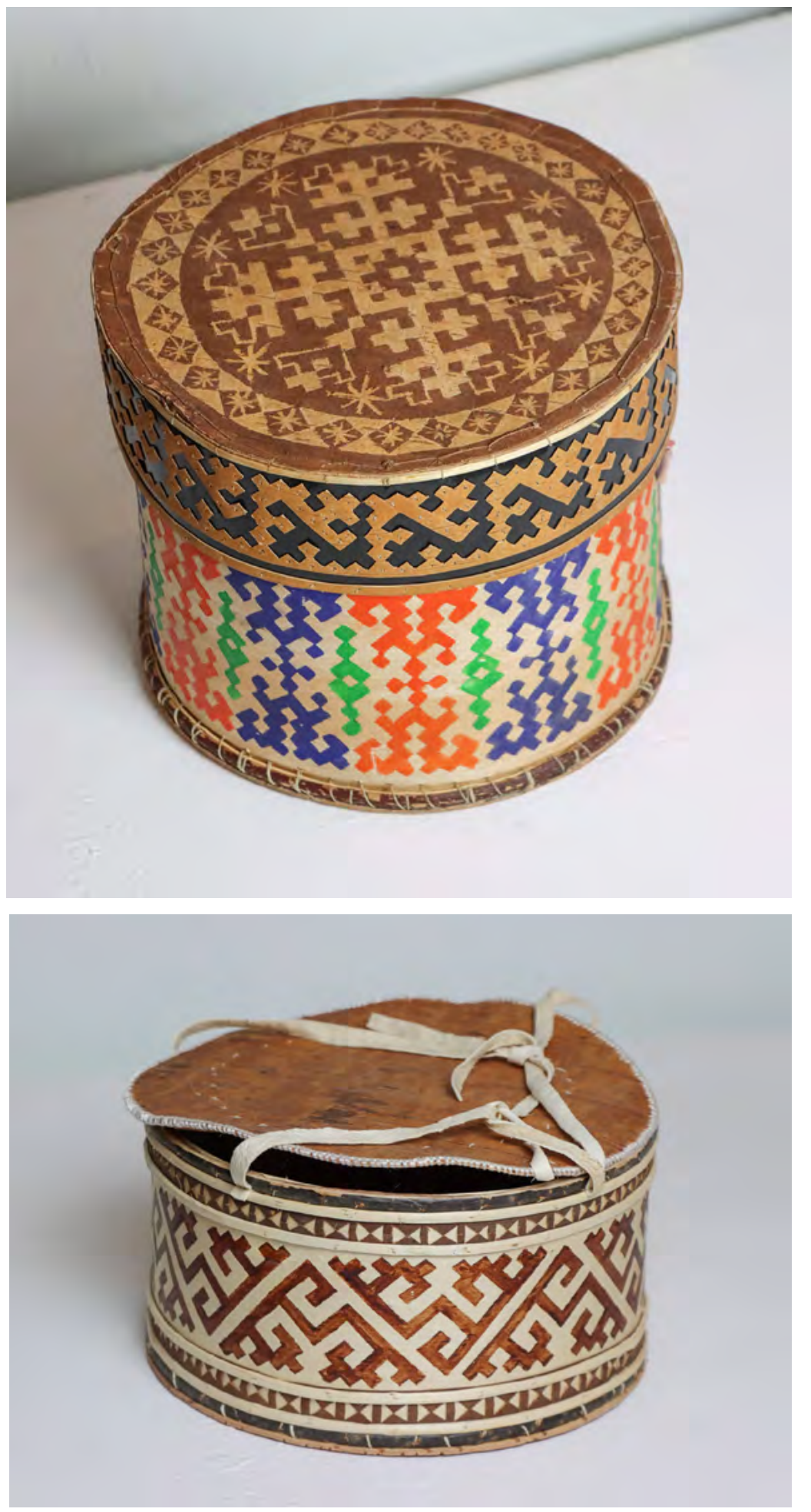

\section{Примечания}

1. Другие названия лодки-долбленки у народов Сибири - облсишко, обласко, обласка, обласок, облос, ибласок. Ходили на таких лодках по сибирским рекам еще 3000 лет тому назад.

2. Остяки и вогулы: так до 1930-х годов назывались народности ханты и манси, а Ханты-Мансийск до 1940 г. носил название Остяко-Вогульск. Другое название остяков (ханты) и вогулов (манси), используемое в научной литературе, - обские угры.

3. Нуми-Торум (букв. «верхний бог») - «небесный 


\section{Искусство Евразии}

\section{№1 (20) 2021 elSSN 2518-7767}

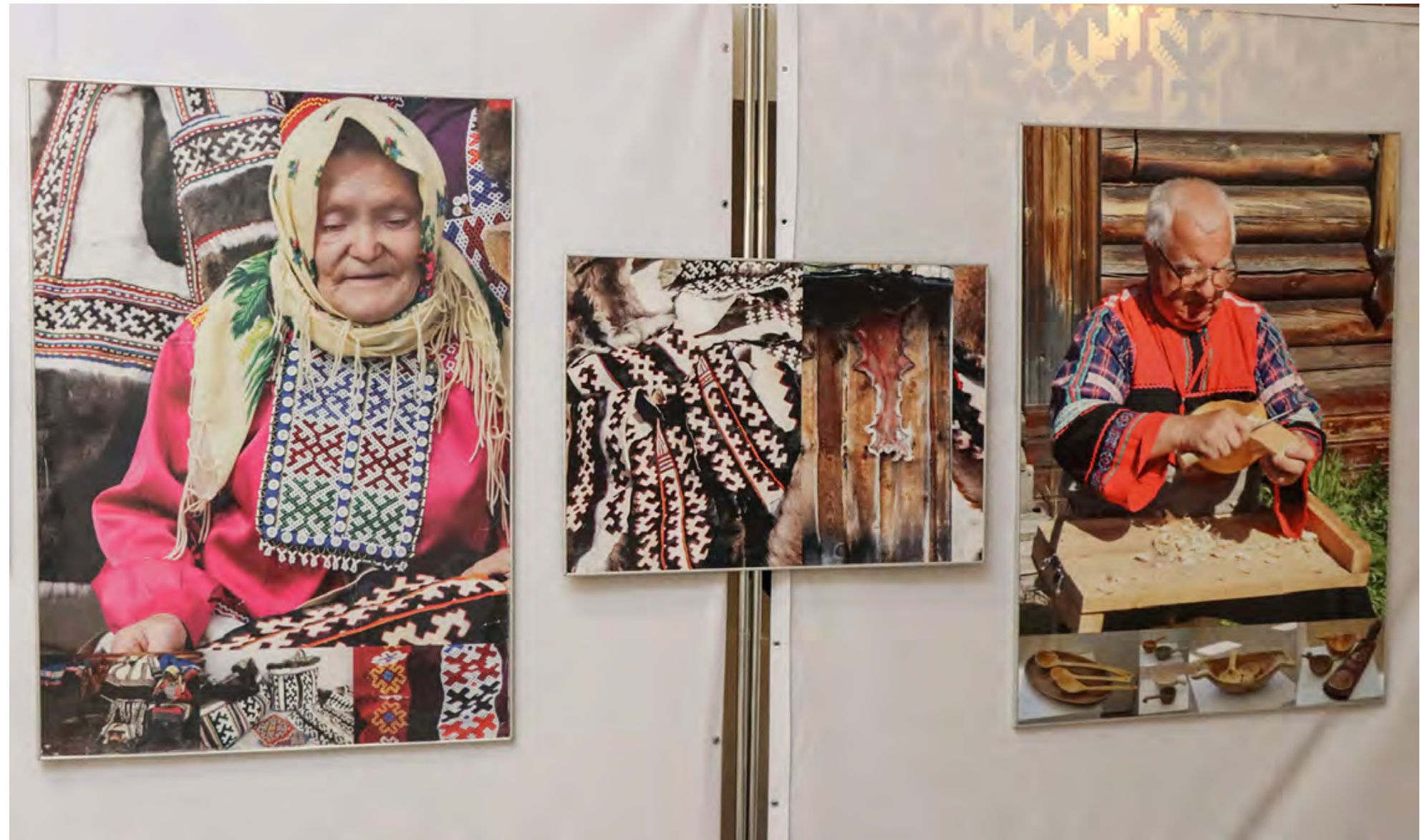

бог», создатель мира в обско-угорской мифологии. Одни из значений слова «торум» — «погода», «небо», «вселенная», «бог».

4. Гагара, утка (или иная водоплавающая птица) - один из образов существа-посредника, встречающийся у разных народов мира. Посредничество выражается в способности путешествовать по трем мирам - небесному, подводному и земному.

5. Ханты и манси учат своих детей лодочному искусству с трех лет: сначала на песке, потом на неглубокой воде у берега.

6. Марьина гора - это уникальная по своим археологическим находкам территория: исторический памятник культуры поздней бронзы, расположенный на территориях г. Урай и п.г.т. Междуреченский, д. Половинка Кондинского района Ханты-Мансийского автономного округа - Югра.

7. Лозьвинская культура (лозьвинский тип керамики) - эпоха поздней бронзы (рубеж II-I тыс. до н.э.). Основным ареалом распространения являются верховья р. Тавды, р. Лозьва, бассейн р. Конды с выходом на Иртыш и в район Заболотья.

«Атлымская культура названа по ключевому памятнику - поселению Малый Атлым-І, расположенному на окраине одноименного поселка в центральной части Нижнего Приобья» [2, с. 76]. Одна из наиболее исследованных первобытных культур таежной полосы Западной Сибири. Относится к эпохе поздней бронзы - переходному от бронзы к железу времени (X-VIII вв. до н.э.).

«Кулайская культура - археологическая культура Западной Сибири с середины I тысячелетия до н.э. до середины I тысячелетия н.э. Разными исследователями кулайская культура связывается с предками самодийцев, угров, кетов» [1]. Ее представители относились к европеоидной и монголоидной расам.

8. Владимир Борисович Кошаев - доктор искусствоведения, профессор Московского государственного университета и Московской государственной художественно-промышленной академии имени С.Г. Строганова, руководитель программ и проектов Министерства образования и науки РФ, заслуженный деятель искусств Удмуртской Республики, постоянный участник и эксперт многих проектов Центра ремесел Югры.
23. Визуальный проект «Лицо мастера». Фото: Центр народных художественных промыслов и ремесел, Ханты-Мансийск, 2020 


\section{Литература}

1. Молодин В.И. Кулайская культура // Историческая энциклопедия Сибири: [в 3 т.] / Институт истории СО РАН. Новосибирск: Историческое наследие Сибири, 2009. URL: http://irkipedia.ru/content/kulayskaya_kultura_istoricheskaya_enciklopediya_sibiri_2009 (Дата обращения: 11.01.2021).

2. Югория: энциклопедия Ханты-Мансийского автономного округа. Т. 1: А-И. / Под ред. В.В. Бакулина и др. Ханты-Мансийск: НИИ региональных энциклопедий ТюмГУ; ИД «Сократ», 2000. 399 с.

\section{References}

1. Molodin V.I. Kulaiskaya kul'tura [Kulay culture]. Istoricheskaya ehntsiklopediya Sibiri [Historical encyclopedia of Siberia]. Novosibirsk, Historical heritage of Siberia Publ., 2009. Available at: http://irkipedia.ru/content/kulayskaya_kultura_istoricheskaya_enciklopediya_ sibiri_2009 (Accessed: 11.01.2021). (In Russian).

2. Bakulin V.V. et al. (eds.). Yugoriya: ehntsiklopediya Khanty-Mansiiskogo avtonomnogo okruga. T. 1: A-I [Yugoria: encyclopedia of the Khanty-Mansiysk Autonomous Okrug. Vol. 1]. Khanty-Mansiysk, Research Institute of Regional Encyclopedias of Tyumen State University; Sokrat Publ., 2000. 399 p. (In Russian).

\section{ИНФОРМАЦИЯ ОБ АВТОРЕ:}

Харитонова Алла Сергеевна - культуролог, специалист по жанрам творчества экспозиционновыставочного отдела, Центр народных художественных промыслов и ремесел, г. Ханты-Мансийск, Российская Федерация. E-mail: alladi@inbox.ru

Илауски Ксения Евгеньевна - заместитель директора, Центр народных художественных промыслов и ремесел, г. Ханты-Мансийск, Российская Федерация. E-mail: centr-remesel@mail.ru

\section{ABOUT AUTHOR:}

Kharitonova, Alla Sergeevna - culturologist, Specialist in creative genres of the Exposition and exhibition department, Center for Folk Arts and Crafts, Khanty-Mansiysk, Russian Federation. E-mail: alladi@inbox.ru

Elowsky, Ksenia Evgenievna - Deputy Director, Center for Folk Arts and Crafts, Khanty-Mansiysk, Russian Federation. E-mail: centr-remese/@mail.ru

\section{Для цитирования $\mid$ For citation:}

Харитонова А.С., Илауски К.Е. Хранители югорских традиций // Искусство Евразии [Электронный журнал]. 2021. № 1 (20). C. 308-319. DOl: https://doi.org/10.46748/ARTEURAS.2021.01.023 URL: https://eurasia-art.ru/index.php/art/article/view/187

Kharitonova A.S., Elowsky K.E. Keepers of Ugric traditions. Iskusstvo Evrazii - The Art of Eurasia, 2021, No. 1 (20), pp. 308-319. DOl: https://doi.org/10.46748/ARTEURAS.2021.01.023 Available at: https://eurasia-art.ru/index.php/art/article/view/187 (In Russian). 